\title{
A EFEMERIDADE DO ASILO ANÁLIA FRANCO NO CENÁRIO DA ASSISTÊNCIA ÀS CRIANÇAS POBRES EM UBERABA-MG $\left(1919\right.$ a 1923) ${ }^{*}$
}

\author{
Marilsa Aparecida Alberto \\ Betânia de Oliveira Laterza Ribeiro \\ Maria Zeneide Carneiro Magalhães de Almeida
}

\section{Introdução}

No final do século XIX e início do século XX, o Brasil passou por uma série de transformações políticas e sociais que concorreram para o crescimento dos centros urbanos e consequente agravamento da pobreza de algumas parcelas da população. Como exemplos é possível citar a entrada de mão de obra imigrante, que contribuiu para o crescimento populacional; o processo de industrialização que, embora incipiente, fez com que inúmeras famílias deixassem o meio rural em direção às cidades; bem como a abolição da escravatura, que não foi acompanhado de reformas voltadas para a proteção dos libertos no processo de transição para o sistema de trabalho livre.

Sobre esse último exemplo, Carvalho (2016, p. 57) lembra que "[...] aos libertos não foram dadas nem escolas, nem terras, nem empregos". Por esse motivo, os ex-escravos que não continuaram trabalhando nas fazendas em troca de baixíssimos salários tiveram que mudar para os centros urbanos, onde contribuíram para "[...] engrossar a grande parcela da população sem emprego fixo" (idem).

Somados aos ex-escravos existia ainda a população livre, mas pobre, que era considerada, desde o contexto da escravidão, "resíduos sociais" ou ainda, "desajustados" que não se enquadravam na bipolaridade de classes da sociedade escravocrata (KOWARICK, 1994). Sobre esse segmento populacional, Patto (1999, p. 174) elucida que:

Na categoria de "vadios" estavam, sim, negros deixados à própria sorte desde a Abolição e objeto de preconceito racial, mas também toda uma gama de "pobres livres" cujo trabalho era socialmente desnecessário. A luta diária pela vida levava-os a improvisar vários tipos de afazeres, desde ocupações autônomas, bicos e subemprego temporário, que

${ }^{*}$ DOI - 10.29388/978-65-86678-49-9-0-f.285-302 
movimentaram a economia informal, até outras formas de sobrevivência, como o roubo, o jogo, a prostituição e a mendicância.

O cenário apresentado contava também com crianças e jovens que desde cedo aprendiam a sobreviver nas ruas às custas da mendicância, da caridade ou da prática de atos considerados ilícitos. Com o tempo, a permanência desse segmento etário pelas vias públicas tornou-se um incômodo e um perigo aos olhos da sociedade.

Nesse contexto, disseminou-se a cultura da institucionalização, ou seja, a ideia de que o recolhimento dessas crianças e jovens em instituições de reclusão era a medida mais eficaz para resolver o problema. Tal medida, além de promover uma assepsia urbana, permitiria a regeneração desses jovens pois, aprendendo algum tipo de ofício, ao saírem das instituições seriam pessoas úteis à sociedade.

A fim de legitimar a atuação do Estado sobre essas crianças, em 1927 foi editado o Código de Menores que prescrevia o tratamento a ser dispensado, especialmente, aos abandonados ou delinquentes (BRASIL, 1927). Em relação aos menores abandonados, o Código previa que eles poderiam ser internados em hospitais, asilos, institutos de educação ou reforma.

Além dessas instituições previstas no Código de Menores, outras modalidades foram criadas ou remodeladas nas primeiras décadas do século XX como as creches, os patronatos, os aprendizados agrícolas, os orfanatos e os asilos, dentre outras. De acordo com Kuhlmann Júnior (2015), esses diversos modelos institucionais foram criados e se organizaram em torno de três influências básicas: a jurídico-policial, a médico-higienista e a religiosa.

Em Uberaba, cidade de tradição agropecuária situada na região do Triângulo, em Minas Gerais, a situação não foi muito diferente. Por meio de consulta realizada em periódicos publicados na primeira metade do século XX, constatou-se que a existência de crianças e jovens pobres nas vias públicas seja mendigando, vadiando ou cometendo travessuras - constituía-se em um problema para a sociedade. Tal fato pode ser evidenciado, por exemplo, neste recorte jornalístico que afirmava: "[...] essa mendicidade generalizada numa terra como a nossa onde se compra zebu por centenas de contos, dá a nossa cidade um aspecto desolador, impressionante, que parece desmentir a abastança e o conforto em que vivemos" (LAVOURA E COMÉRCIO, 09/11/1919, p. 2).

Diante desse cenário, a cidade de Uberaba também se preocupou com a criação de instituições que pudessem recolher essas crianças, retirando-as das ruas. Assim, nas primeiras décadas do século XX, surgiram na cidade algumas entidades assistenciais católicas e espíritas, públicas e privadas, voltadas para meninos ou para meninas. Tal fato corrobora o que foi pontuado por Rizzini e Rizzini (2004, p. 22) ao afirmarem que as crianças passaram a ser "[...] alvo 
específico da intervenção formadora/formadora do Estado e de outros setores da sociedade, como as instituições religiosas e filantrópicas.".

Dentre as instituições que atenderam crianças pobres na cidade de Uberaba na primeira metade do século XX, foram levantados, até o momento, o Asilo da Mendicidade (1915), o Aprendizado Agrícola Borges Sampaio (1916), o Asilo Anália Franco (1919), o Orfanato Santo Eduardo (1920), o Abrigo de Menores Leopoldino de Oliveira (1940), o Externato São José (1947) e o Lar Espírita de Uberaba (1949), conforme dados disponíveis em Souza (2018).

Este capítulo tratará, especificamente, do Asilo Anália Franco, cuja existência foi efêmera, de 1919 a 1923. O objetivo do presente capítulo é apresentar a gênese da instituição e os motivos pelos quais sua existência foi tão curta. O capítulo também tem como objetivo identificar se o tratamento dispensado às internas tinha como perspectiva a regeneração social por meio da preparação para o trabalho, como era comum nesse modelo institucional. Antes, porém, serão apresentados, de forma breve, alguns dados sobre Anália Franco e sua atuação educativa e assistencial junto às crianças pobres no estado de São Paulo.

\section{Anália Franco}

De acordo com a biografia de Anália Franco apresentada por Kishimoto (1986), ela nasceu em 1853, em Rezende-RJ, e morreu em 1919, em São Paulo, vítima da gripe espanhola. Aos 18 anos completou seus estudos na Escola Normal, também em São Paulo. Além de professora, desenvolveu atividades assistenciais, iniciando sua atuação em meio aos eventos ocorridos após a Lei do Ventre Livre, que transformou os nascituros de escravos em crianças predestinadas às Rodas dos Expostos. Posicionando-se como abolicionista, iniciou suas atividades socioeducacionais junto às crianças negras e abandonadas, dando assistência àquelas que eram expulsas das fazendas e começavam a mendigar pelas ruas.

No final do século XIX, a primeira Casa Maternal criada por Anália Franco, em São Paulo, foi alvo de perseguições da sociedade da época, uma vez que atendia, de forma indistinta, crianças brancas e negras. A proprietária do estabelecimento onde funcionava a Casa Maternal propôs a Anália Franco a isenção do pagamento do aluguel, desde que ela não transformasse seu imóvel em um "albergue de negrinhos" (KISHIMOTO, 1986, p. 212). Obrigada a procurar outro local para instalar sua obra assistencial, e sem recursos, Anália Franco teve que pedir esmolas nas casas, junto com as crianças, situação que não foi bem vista pela sociedade da época. 
Devido à sua perseverança, apesar das dificuldades encontradas, Anália Franco já havia inaugurado, em 1910, 18 escolas maternais e 17 creches-asilos em todo o estado. Além do trabalho assistencial junto às crianças, a obra de Anália Franco também era voltada para a profissionalização de mães, mulheres trabalhadoras e órfãos de maior idade (KUHLMANN JÚNIOR, 2009). Além disso, ela participou da fundação da Associação Feminina Beneficente e Instructiva de São Paulo - AFBI - responsável pela organização dessas casas de assistência.

De acordo com o estatuto da AFBI, essas instituições teriam um caráter espiritualista, porém deveriam ser leigas, respeitando as diversas crenças das sócias e das pessoas acolhidas. Entretanto, a adesão de Anália Franco ao espiritismo e o recebimento de financiamento maçônico contribuíram para o surgimento de conflitos com a Igreja Católica que, por meio dos jornais, denunciava as instituições ligadas à AFBI como "espíritas" e "perigosas".

As disputas travadas no final do século XIX e primeiras décadas do século XX entre a Igreja Católica e o Espiritismo envolveram discussões e condenações doutrinárias. Contudo, oportunizaram a realização de ações caritativas e obras sociais como objeto dessas contendas. Conforme Camurça (2000, p. 132), “[...] a virtude cristã da prática da caridade, cuja centralidade é marcante nas duas tradições religiosas, passa a ser utilizada como mecanismo de desqualificação e legitimação no processo de competição religiosa entre Catolicismo e Espiritismo.”.

Tal situação pode ser percebida, inclusive, no município de Uberaba, pois no ano seguinte ao da instalação do Asilo Anália Franco, destinado à assistência de meninas, os católicos criaram o Orfanato Santo Eduardo, voltado para o mesmo público, sendo que uma das motivações para sua criação foi o combate ao avanço do espiritismo (SOUZA, 2018).

\section{O Asilo Anália Franco em Uberaba}

Em 1918, Anália Franco resolveu inaugurar um local para assistência às crianças pobres na cidade de Uberaba. A criação desse asilo em solo mineiro foi inusitada e peculiar, uma vez que a maior parte das instituições criadas por Anália Franco estava situada no estado de São Paulo. Tudo indica que a escolha por Uberaba tenha ocorrido devido à existência de alguns amigos na cidade:

Pouco antes da partida de Anália Franco para o mundo espiritual, já muito doente e esgotada em seu físico, quis dar andamento ao seu desejo de criar mais um abrigo creche na cidade de Uberaba, Minas Gerais. Ela havia se comprometido com seu grande amigo, pessoa muito influente na cidade de Uberaba, e que muito a ajudou quando lá esteve, o Dr. Antônio Ribeiro, em criar um abrigo. Dizia ele que era de suma importância, 
pois os enjeitados ali eram em grande número e ele achava que o projeto de Anália em criar esses abrigos, fazendo deles um verdadeiro lar, era o que faltava para que as crianças não ficassem mais ao desamparo. Como Anália já não tinha mais saúde para tanto, passou essa responsabilidade para sua interna amiga, dona Clélia Rocha que, como professora, lecionando no Rio de Janeiro e voluntária da escola maternal carioca fundada por Anália, imediatamente deixou seu estado e transferiu-se para Uberaba. Acompanhou o desenvolvimento dessa obra, que foi inaugurada sem a presença de Anália Franco, que veio a desencarnar em São Paulo, no dia 20 de janeiro de 1919 (ELOISA, 2007, p. 11).

Acerca de Clélia Rocha, consta que ela nasceu em 1886, em Barra Mansa-RJ. Após receber o diploma de professora primária, passou a lecionar em um colégio de freiras. A seguir, abriu um estabelecimento de ensino na cidade de Dourados, destinado à alfabetização de adultos. Nessa época conheceu Anália Franco, sendo convidada a fazer parte de sua equipe de trabalho. Tornaram-se grandes amigas e mútuas colaboradoras (GODOY, 1990).

A escolha de Clélia Rocha para a direção do asilo a ser fundado em Uberaba não foi aleatória. Anália Franco depositava irrestrita confiança em seu trabalho, chegando a afirmar, em uma de suas cartas, que ela era " [...] a diretora que mais assimilou os nossos ideais e muito tem produzido. Se todas as demais cooperadoras fizessem como você, muito realizaríamos" (GODOY, 1990, p. 75).

Clélia Rocha, então, transferiu a instituição fundada em Dourados para a cidade de Uberaba, inaugurando-a em 1919, quando Anália Franco já havia falecido. Assim como Anália, que encontrou inúmeras dificuldades para inaugurar e manter suas escolas em São Paulo, o vínculo de Clélia Rocha com o espiritismo e o apoio recebido da maçonaria também serviram de obstáculos para o desenvolvimento de seu trabalho assistencial.

De acordo com Godoy (1990, p. 75), Clélia Rocha “[...] pleiteou por várias vezes subvenções municipais, estaduais e federais, nunca conseguindo ressonância para as suas petições pois, pelo fato de ser espírita, intensa perseguição lhe foi movida pelos sacerdotes locais". Além disso, o Asilo Anália Franco foi vítima de perseguição moral, chegando a ser acusado de maltratar as internas. Ludovice Fernandes, um dos fundadores do Sanatório Espírita de Uberaba, mandou publicar uma nota no jornal em defesa da instituição:

Sciente de que pessoas inclinadas a calunia e a difamação propagam na cidade que as creanças orphas do "Colégio Anália Franco" são barbaramente espancadas, e como sempre fui, franco em hora, e defensor dos oprimidos, dos que batem pelo ideal do Bom e do Justo, venho protestar energicamente contra essa torpe e vil calunia porquanto conheço, de perto, como são tratadas ali as creanças, as quaes não faltam 
carinho e amor, uma extensão mais lata do termo, proporcionados não só pelas professoras como pela Diretora que se acha ausente em viagem de escursão, trabalhando com o seu grupo dramatico para a manutenção dos orphãosinhos desamparados e entregues a sua inteligente direcção. É, pois, em nome da Directora que torno publico este protesto, ajustando que, para a pessoa que acaba de retirar daquele tecto protector duas filhinhas suas, onde recebiam toda sorte de cuidados e carinhos, seriam aplicadas as penas do Codigo Penal da Terra, se porventura ali não fosse religiosamente o Código Daquelle que, despedindo-se das miseráveis perseguições terrenas, disse aos seus algozes: - Perdoae-lhes, meu pae, por que elles não sabem o que fazem. Entretanto, fica franqueado ao publico e aos interessados, ás pessoas sensatas e criteriosas aquele estabelecimento para verificarem o que acima ficou dito (LAVOURA E COMÉRCIO, 11/12/1919, p. 8).

Sem receber recursos para manter a obra assistencial que atendia 72 asiladas, Clélia Rocha teve que lançar mão de outros expedientes para conseguir atender suas alunas de forma gratuita. Um deles foi abrir as portas a pensionistas, que chegaram ao número de dezoito, para participarem dos cursos de música, costura, flores e bordado. A instituição também aceitava encomendas dos produtos confeccionados pelas cursistas. Para atrair a população foram publicados anúncios na imprensa local:

Acha-se aberta a officina de costura no Collegio Analia Franco, pronto a receber encomendas de qualquer natureza. Recebe alumnas para aprender a costurar e cortar cobrando $19 \$ 000$ mensaes; entrada das 11 horas até ás quatro da tarde. As alumnas de costura serao sujeitas a disciplina do Collegio [...] só saindo as 4 horas da tarde, juntamente com as alumnas do colégio. Nesse ponto de vista os senhores pais podem ficar tranquilos, e a disciplina nas officinas será exigente em certo ponto de vista, visando a inteira confiança das familias. As alumnas que quizerem tomar lanche no colegio e mesmo jantar pagarao mais, mediante previa combinação. Clélia Rocha. Directora (LAVOURA E COMÉRCIO, 23/10/1919, p. 3).

Por esse anúncio é possível levantar algumas suposições acerca da instituição. Nota-se, por exemplo, que nem todas as crianças atendidas eram desprovidas de um lar, visto que elas saiam do estabelecimento às quatro da tarde para retornarem a suas casas. Depreende-se, então, que o Asilo possivelmente atendia a três diferentes grupos: crianças que moravam na instituição e crianças que moravam com suas famílias, sendo que dentre essas últimas, existiam as que pagavam e as que frequentavam de forma gratuita. Essa diferenciação da clientela também pode ser depreendida quando se observa a forma como a instituição era designada no anúncio: "Asilo-Colégio Anália Franco". 
O Asilo também contava com o auxílio da Loja Maçônica Estrela Uberabense, que além de ajudar com a quantia mensal de 200 mil réis, enviava donativos arrecadados no comércio local (FERREIRA, 1987). Outra forma de obter recursos foi por meio do Conjunto Lítero-Artístico e Musical, que exibia apresentações nas cidades do interior dos estados de São Paulo e Minas Gerais para angariar fundos para a instituição (GODOY, 1990).

Além dos cursos mencionados, o Asilo também ofertava ensino primário, fato ratificado em nota publicada no jornal, em dezembro de 1919, elencando as alunas que, após realização dos exames, estavam aptas a passarem para o primeiro, segundo e terceiro ano.

Seis meses após a instalação da instituição em Uberaba, Clélia Rocha mandou publicar a seguinte nota no jornal:

Respeitavel publico de Uberaba, antes de abordar o principal assunpto, dir-vos-ei que absolutamente não tenho outro ideal alem de abraçar tantas orfãs, quantas possa educar, e para isso conto com o apoio da esclarecida população de Uberaba. Não aspiro as honras da terra, nem o metal adorado pela humanidade; só desejo e trabalho muito para que neste humilde lar, mantido pelos meus esforços, meus sacrificios, não falte pão e agasalho aos infelizes filhos do infortunio dispersos nesta querida terra de Minas. Aqui estou sem outro fim além do ideal de arrancar da miseria as orfãs, cujo destino lhes roubou o tecto que se chama lar. Neste recanto de Minas, acha-se, pois instalado o Asylo para abrigo de orfãos, completamente desligado de compromissos com outra Instituição e prompto a trabalhar pelos pobres filhinhos sem pais. Quis o destino que eu viesse habitar o glorioso Estado de Minas pois aqui, rodeada de uma familia enorme que symbolisa a caridade, e inteiramente livre de qualquer compromisso, declaro-me inteiramente pronta a trabalhar pela humanidade. Sei perfeitamente que os mineiros de coração, os mineiros de elevado sentimento, hão de prontificar-se também a vir com o seu braço forte auxiliar a esta Instituição de caridade, hoje também mineira. Senhores, homens esclarecidos, filhos de um paiz liberto como o nosso querido Brazil, dizei-me: que merece aquelle que se sacrifica pelo beneficio do próximo? - Merece que se lhe oprima? Merece que se lhe procure embaraçar-lhe os passos? Ah! Estou certa de que, dentro do coração verdadeiramente brasileiro e particularmente mineiro há um ecco que supplanta a fraqueza dos egoistas, os preconceitos absurdos e a má vontade dos ignorantes [...]. De acordo com pessoas amigas e que se interessam pela causa ficou determinado e foi resolvido que este asylo, hoje mineiro, se desligasse, passando a viver independente. Portanto o Asylo Creche e Collegio Analia Franco, conserva do passado unicamente a memoria da sua fundadora, respeita os seus methodos em parte, e no denodado exemplo dessa heroina trabalhará para manter-se digno de figurar no gloriosos 
Estado de Minas Gerais. A diretora, Clélia Rocha (LAVOURA E COMÉRCIO, 25/09/1919, p. 6).

Conforme observado, as palavras de Clélia Rocha eram um desabafo acerca das dificuldades encontradas, referentes tanto à falta de recursos quanto às perseguições sofridas devido a sua filiação religiosa. Também chama a atenção o fato de a instituição estar se desvinculando da obra paulista de Anália Franco, ou seja, da AFBI, passando a viver de forma independente.

De acordo com Oliveira (2007), após a morte de Anália Franco vieram à tona algumas divergências no interior da AFBI, motivadas por questões administrativas e financeiras, fazendo com que diversas instituições pedissem seu desligamento. Além disso, o novo estatuto determinava que não seria tolerada a manutenção de instituições fora de São Paulo, situação que justifica o pronunciamento de Clélia Rocha.

Diante dos percalços encontrados, tanto em relação à AFBI como em relação à sociedade católica uberabense, no ano de 1923 Clélia Rocha encerrou suas atividades e foi para São Manuel-SP, onde fundou o Lar Anália Franco. Levou, inclusive, algumas meninas que eram internas em Uberaba. Mesmo após a morte de Clélia Rocha, ocorrida em 1936, o Lar Anália Franco de São Manuel continuou suas atividades assistenciais, funcionando, inclusive, ainda atualmente.

\section{Práticas educativas no Asilo Anália Franco}

Dentre as diversas internas que passaram pelo Asilo Anália Franco em Uberaba, uma delas, chamada Olga, entrou para a instituição aos sete anos de idade, em 1920. Mais tarde, Olga foi transferida para o Lar Anália Franco em São Manuel e lá permaneceu até 1943, quando se casou. Diversos acontecimentos vividos por Olga, tanto no Lar quanto fora dele, foram registradas por meio de fotografias, as quais foram organizadas por sua filha Eleonora Sampaio Caselato no material intitulado "O Álbum de Olga". Nesse Álbum, Eleonora também registrou comentários feitos por sua mãe enquanto ela manuseava os retratos. Algumas dessas fotografias, apresentadas a seguir, permitem conhecer um pouco do cotidiano do Asilo Anália Franco, tanto em Uberaba como em São Manuel.

Na Figura 1, é possível divisar um grupo de crianças do Lar Anália Franco. Acredita-se que a fotografia foi tirada em Uberaba pois, de acordo com

\footnotetext{
${ }^{1} \mathrm{O}$ "Álbum de Olga", cujas fotos pertencem ao acervo pessoal de Eleonora Sampaio Caselato, está disponível na página da rede social Facebook intitulada "História Viva do Lar Anália Franco de São Manuel”. Trata-se de uma página criada por amigos e ex-internas do Lar Anália Franco.
} 
os relatos de Olga, sua irmã, que está presente na fotografia, falecera nessa cidade, antes da transferência do Asilo para São Manuel.

Figura 1 - Internas do Asilo Anália Franco em Uberaba - s.d

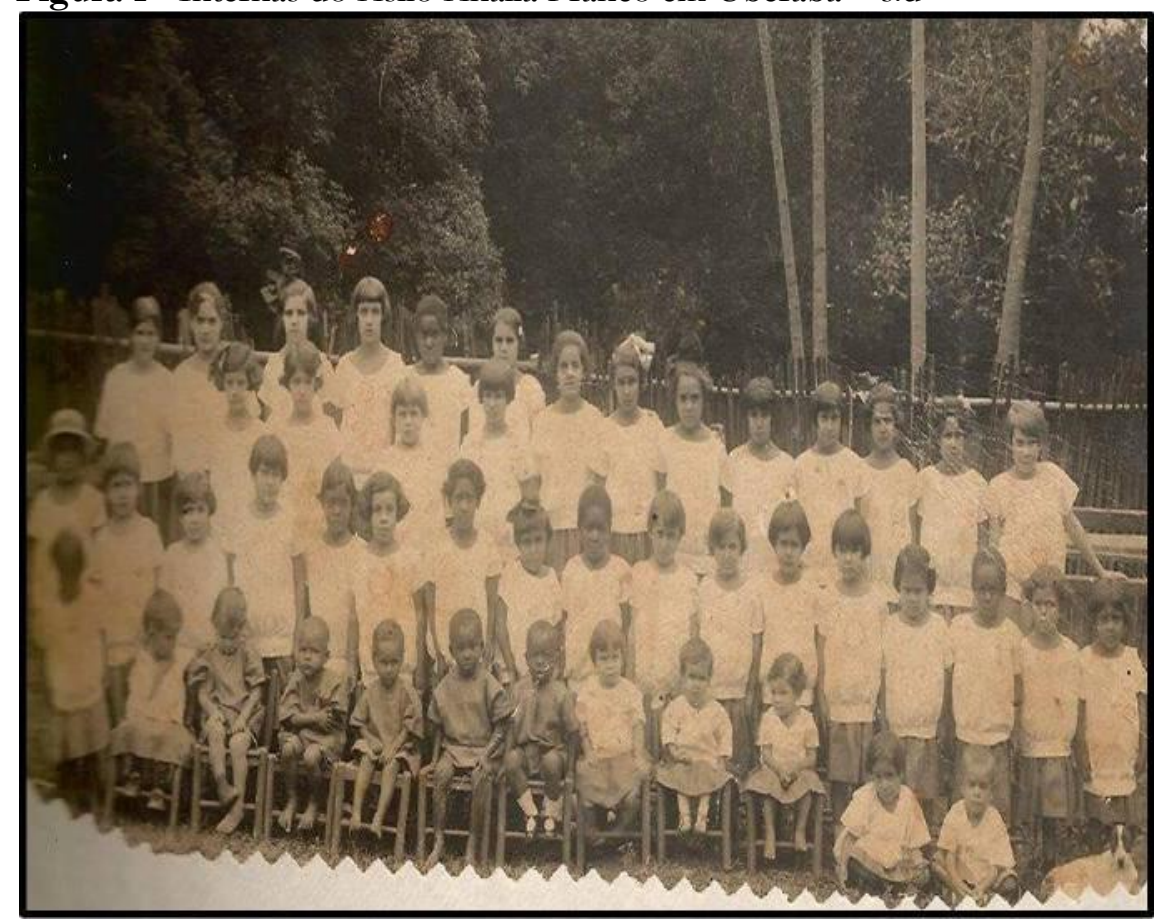

Fonte: Caselato (2003).

De acordo com Kossoy (2009, p. 143),

As fotografias, em geral, sobrevivem após o desaparecimento físico do referente que as originou: são os elos documentais e afetivos que perpetuam a memória. A cena gravada na imagem não se repetirá jamais. O momento vivido, congelado pelo registro fotográfico, é irreversível. As personagens retratadas envelhecem e morrem, os cenários se modificam, se transfiguram e também desaparecem. O mesmo acontece com os autores-fotógrafos e seus equipamentos. De todo o processo, somente a fotografia sobrevive. Os assuntos nela registrados atravessam os tempos e são hoje vistos por olhos estranhos em lugares desconhecidos: natureza, objetos, sombras, raios de luz, expressões humanas, por vezes crianças, hoje mais que centenárias, que se mantiveram crianças. 
As palavras de Kossoy expressam com primor a sensação que se tem diante da imagem retratada na Figura 1. Tirada possivelmente entre 1919 e 1923, as pessoas dessa fotografia, se estiverem ainda vivas, são centenárias, embora o retrato tenha congelado no tempo seus rostos e corpos infantojuvenis.

Além disso, é possível supor que o cenário que compõe a fotografia se modificou, se transfigurou ou até mesmo desapareceu, conforme sugerido por Kossoy (2009). Entretanto, restou a fotografia com a qual é possível estabelecer um diálogo, na tentativa de desvelar aspectos inerentes à instituição e aos sujeitos que dela fizeram parte.

Nota-se, primeiramente, que se trata de um modelo clássico de fotografia na qual internas e internos foram cuidadosamente dispostos de forma a conferir ordem e simetria à imagem: maiores atrás e menores à frente. A pose, as vestimentas e os cortes de cabelo também contribuem para o equilíbrio da imagem. A propósito, a semelhança desses cortes permite reportar a Goffman (1974), que utiliza a expressão "estojo de identidade" em referência ao conjunto de bens individuais que têm estrita relação com o eu. Assim,

[...] a pessoa geralmente espera ter certo controle da maneira de apresentar-se diante dos outros. Para isso precisa de cosméticos e roupas, instrumentos para usá-los, ou consertá-los, bem como de um local seguro para guardar esses objetos e instrumentos [...]. No entanto, ao ser admitido numa instituição total, é muito provável que o indivíduo seja despido de sua aparência usual, bem como dos equipamentos e serviços com os quais a mantém, o que provoca desfiguração pessoal. (GOFFMAN, 1974, p. 28).

Observa-se, assim, que o corte do cabelo - característica que permite distinguir e conferir identidade às pessoas - acabou sendo submetido à imagem pretendida por terceiros. Entretanto, cabe observar que a exigência de cabelos curtos, naquela conjuntura, também pode ser vista como uma medida de higiene para evitar a proliferação de piolhos.

Pela fotografia também é possível antever o perfil da clientela atendida: crianças e jovens de idades variadas, a maior parte meninas e moças, públicoalvo da instituição. Entretanto, é curioso constatar a presença de cinco garotos que, com suas vestes diferenciadas, contrastavam com as meninas uniformemente vestidas.

Em outra fotografia do Álbum referente à fase em que o Asilo já estava em São Manuel, Olga fez o seguinte comentário na fotografia de um rapaz: "Chegou no Lar trazido pela mãe. Era menino, mas ficou porque a mãe disse que não ia mesmo ficar com ele" (CASELATO, 2003, p. 128). Essa informação permite supor que, embora tendo como objetivo prestar assistência a meninas, 
Clélia Rocha também acolhia meninos que não tinham para onde ir, situação que possivelmente explica a presença desses cinco garotos na imagem.

A Figura 2 apresenta, em seu lado direito, a fotografia de Clélia Rocha, também conhecida como D. Lily, segurando um livro. A seus pés, uma criança chamada Cidinha. A presença do livro nas mãos de Clélia Rocha não foi aleatória. Fiel discípula de Anália Franco, ela seguiu os ensinamentos de sua mentora, que estava sempre "[...] cultivando a leitura e a escrita, não se contentando apenas com as atividades voltadas para o aprimoramento das prendas domésticas" (OLIVEIRA, 2007, p. 25).

Figura 2 - Clélia Rocha e Cidinha - s.d

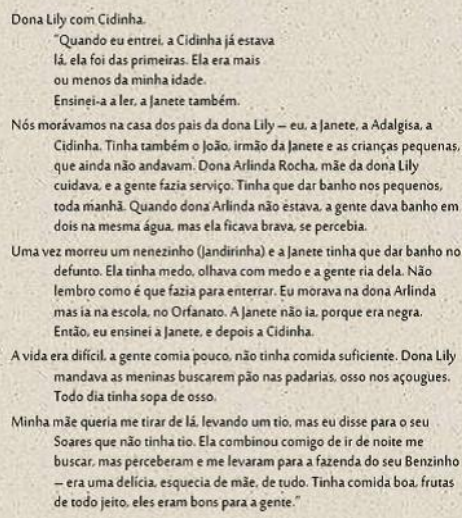

Uma vez morreu um nenezinho (Jandirinha) e a Janete tinha que dar banho no defunto. Ela tinha medo, olhava com medo e a gente ria dela. Não lembro como é que fazia para enterrar. Eu morava na dona Arlinda mas ia na escola, no Orfanato. A Janete nảo ia. porque era negra. Entào, eu ensinei a janete, e depois a Cidinha.

A vida era difíil. a gente comia pouco, não tinha comida suficiente. Dona Lily mandava as meninas buscarem păo nas padarias, osso nos açougues. Todo dia tinha sopa de osso

Minha mãe queria me tirar de lá. levando um tio, mas eu disse para o seu Soares que não tinha tio. Ela combinou comigo de ir de noite me buscar, mas perceberam e me levaram para a fazenda do seu Benzinho - era uma delicia esquecia de mãe, de tudo. Tinha comida boa, frutas de todo jeito, eles eram bons para a gente."

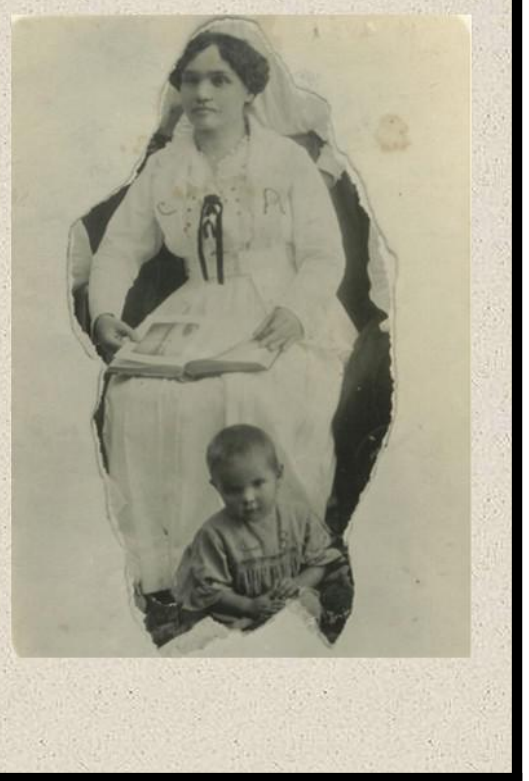

Fonte: Caselato (2003).

O lado esquerdo da imagem apresenta as palavras de Olga, transcritas a seguir:

D. Lily com Cidinha. "Quando eu entrei, a Cidinha já estava lá, ela foi das primeiras. Ela era mais ou menos da minha idade. Ensinei-a a ler, a Janete também. Nós morávamos na casa dos pais da dona Lily - eu, a Janete, a Adalgisa, a Cidinha. Tinha também o João, irmão da Janete e as crianças pequenas, que ainda não andavam. Dona Arlinda Rocha, mãe da dona Lily cuidava, e a gente fazia serviço. Tinha que dar banho nos 
pequenos, toda manhã. Quando dona Arlinda não estava, a gente dava banho em dois na mesma água, mas ela ficava brava, se percebia. Uma vez morreu um nenezinho (Jandirinha) e a Janete tinha que dar banho no defunto. Ela tinha medo, olhava com medo e a gente ria dela. Não lembro como é que fazia para enterrar. Eu morava na dona Arlinda mas ia na escola, no Orfanato. A Janete não ia, porque era negra. Então, eu ensinei a Janete, e depois a Cidinha. A vida era difícil, a gente comia pouco, não tinha comida suficiente. Dona Lily mandava as meninas buscarem pão nas padarias, osso nos açougues. Todo dia tinha sopa de osso. Minha mãe queria me tirar de lá, levando um tio, mas eu disse para o seu Soares que não tinha tio. Ela combinou comigo de ir de noite me buscar, mas perceberam e me levaram para a fazenda do seu Benzinho era uma delícia, esquecia de mãe, de tudo. Tinha comida boa, frutas de todo jeito, eles eram bons para a gente" (CASELATO, 2003, p. 97).

O texto que acompanha a fotografia fornece algumas pistas que permitem dimensionar como era a vida daquelas crianças. As palavras apresentadas reafirmam a suposição de que a instituição não funcionava apenas em regime de internato. Entretanto, crianças que não tinham família ou aquelas cujas famílias não tinham condições de sustentá-las, moravam na casa dos pais de Clélia.

É bastante intrigante a citação de Olga na qual ela diz que "[...] a Janete não ia [à escola], porque era negra" (CASELATO, 2003, p. 97). Considerando que as obras iniciais de Anália Franco tiveram como foco prestar assistência às crianças negras abandonadas, o fato de a jovem não frequentar a escola devido a sua raça causa estranhamento. As palavras ditas por Olga também permitem reafirmar as dificuldades financeiras pelas quais o Asilo passou. Também chama a atenção, em outras passagens do Álbum, as referências feitas às trocas dos nomes das meninas:

Janete era Sebastiana, ficou Joana porque tinha outra Sebastiana. Ela mesma se nomeou Janete, quando cresceu e foi para o palco. Janete tinha cinco irmãos, três homens (João, Zezinho e Leonardo) e duas mulheres (Luiza e Ana). Dona Lily pegou quatro. Eles eram de Santa Rosa do Viterbo. Um dia, chegou uma carta perguntando se lá no Lar, morava uma pessoa com nome Dúlia. Janete chorou muito porque esse era o nome pelo qual ela era chamada, em sua casa. A pessoa que procurava por ela era Ana, sua irmã. Começaram a se corresponder. Janete tinha uma irmã chamada Elisa, mas como tinha outra com o mesmo nome, dona Lily mudou para Luiza. Dona Lily mudava muito os nomes, não gostava de alguns nomes e simplesmente trocava - Antonia virou Dalva (nome lindo, de estrela). O Pescador também era irmão de Janete. Seu nome era Leonardo e ele tinha esse apelido porque numa das peças do teatro tinha o Leonardo - o pescador (CASELATO, 2003, p. 60). 
Algumas instituições, principalmente religiosas, tinham o costume de trocar os nomes dos sujeitos no momento da admissão como forma simbólica de promover uma ruptura com o passado e o mundo exterior. Para Goffman (1974), a mudança do próprio nome é uma das formas de mutilação do eu, pois contribui para a perda da identidade do indivíduo.

No caso das crianças do Asilo, as trocas eram feitas quando Clélia não gostava do nome ou quando já havia alguém com outro igual. Ainda em relação a esse assunto, consta que quando Clélia Rocha precisava regularizar os documentos das crianças enjeitadas deixadas no Asilo, ela fazia o registro com seu próprio nome (GODOY, 1990).

Outros relatos presentes no Álbum de Olga permitem conhecer um pouco mais sobre o cotidiano institucional. Mesmo que essas passagens sejam referentes ao momento em que o Asilo já estava instalado em São Manuel, as práticas possivelmente eram parecidas com aquelas vivenciadas em Uberaba:

Além das atividades do teatro e da banda, as meninas e moças do Orfanato Anália Franco tinham obrigações com a casa, revezando-se nas tarefas do dia-a-dia; estudavam, pois sempre havia professoras na casa [...]. Cada uma das maiores tinha a responsabilidade de cuidar de uma, ou mais, das menores (eram as "mães" das pequenas); aprendiam a costurar, fazer flores e bordados [...]. Dona Elvira era professora de corte e costura, mandava a gente alinhavar, desmanchar, costura. A Adalgisa era a chefe da oficina e quando ela casou, eu tive que ficar no lugar dela, para fazer roupa para as crianças [...]. Seu Benzinho (Manoel Maciel) tinha uma filha no externato dirigido por Dona Lily em Uberaba. Seu nome era Lourdes. Ele gostava muito da dona Lily e tinha gratidão pelo estudo da filha, por isso levava as crianças para passar temporadas na sua fazenda em Igarapava e em outra, em Limeira [...] (CASELATO, 2003, p. $50)$.

A rotina das integrantes do Lar Anália Franco era bastante semelhante à de outras instituições assistenciais femininas nas quais as internas estudavam, ajudavam nos serviços domésticos, cuidavam das crianças menores e, ainda, aprendiam atividades manuais consideradas próprias do ambiente feminino: costurar, bordar, fazer arranjos de flores etc.

Entretanto, a instituição conduzida por Clélia Rocha possuía um diferencial que conferia ludicidade à proposta pedagógica: as atividades teatrais, de dança e de música, bem como as viagens pelas cidades do interior nas quais as jovens faziam apresentações. A inclusão dessas atividades lúdicas e artísticas permite deduzir que Clélia Rocha procurava manter os princípios educativos adotados por Anália Franco que, por sua vez, foi influenciada por pensadores europeus. 
A propósito, pesquisadores que se debruçaram sobre a obra de Anália Franco como Kishimoto (1986), Monteiro (2004) e Lodi-Corrêa (2009), concluíram que a metodologia por ela adotada era coerente com os princípios de pensadores como Froebel, Montessorie e, sobretudo, Pestalozzi:

Anália Franco, próxima da proposta pestalozziana, adere à moral cristã sem rótulos religiosos específicos, usa sempre a arte, prepara os próprios alunos para serem mestres e valoriza o aprendizado profissional. A arte pode ser detectada principalmente na formação do grupo dramático musical fundado pela educadora [...]. $\mathrm{E}$ as oficinas tipográficas, de flores, costuras entre outras visavam ao aprendizado profissional. Os educandos de Anália puderam aprender, de acordo com suas aptidões: música, dramaturgia, confeccionar flores artificiais, costuras e bordado, carpintaria, trabalho na tipografia [...]. Anália Franco utilizava o método intuitivo, trabalhando com a percepção do aluno. Em seus manuais, a educadora sugere essa forma de aprendizado. A princípio sem usar o nome sugere as lições de coisas: o método consiste sobretudo na explicação de cada cousa e quanto possível na vista mesmo do objeto [...] Já no relatório de 1908 deixa claro que o método de ensino da creche é o intuitivo (LODICORRÊA, 2009, p. 112-113, grifo nosso).

Nas Figuras 3 e 4 é possível contemplar algumas fotografias das jovens nas quais estão presentes Olga e, possivelmente, outras jovens que fizeram parte da instituição quando ela esteve instalada em Uberaba.

Figura 3 - Orquestra do Lar Anália Franco

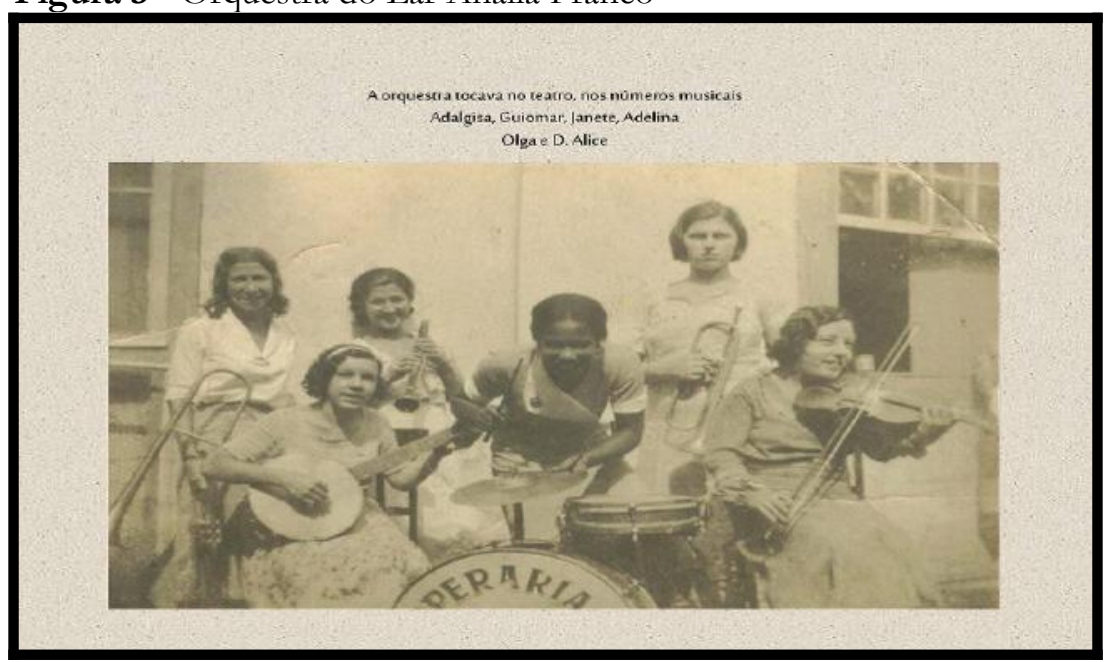

Fonte: Caselato (2003). 
Figura 4 - Grupo de Dança do Lar Anália Franco - s.d

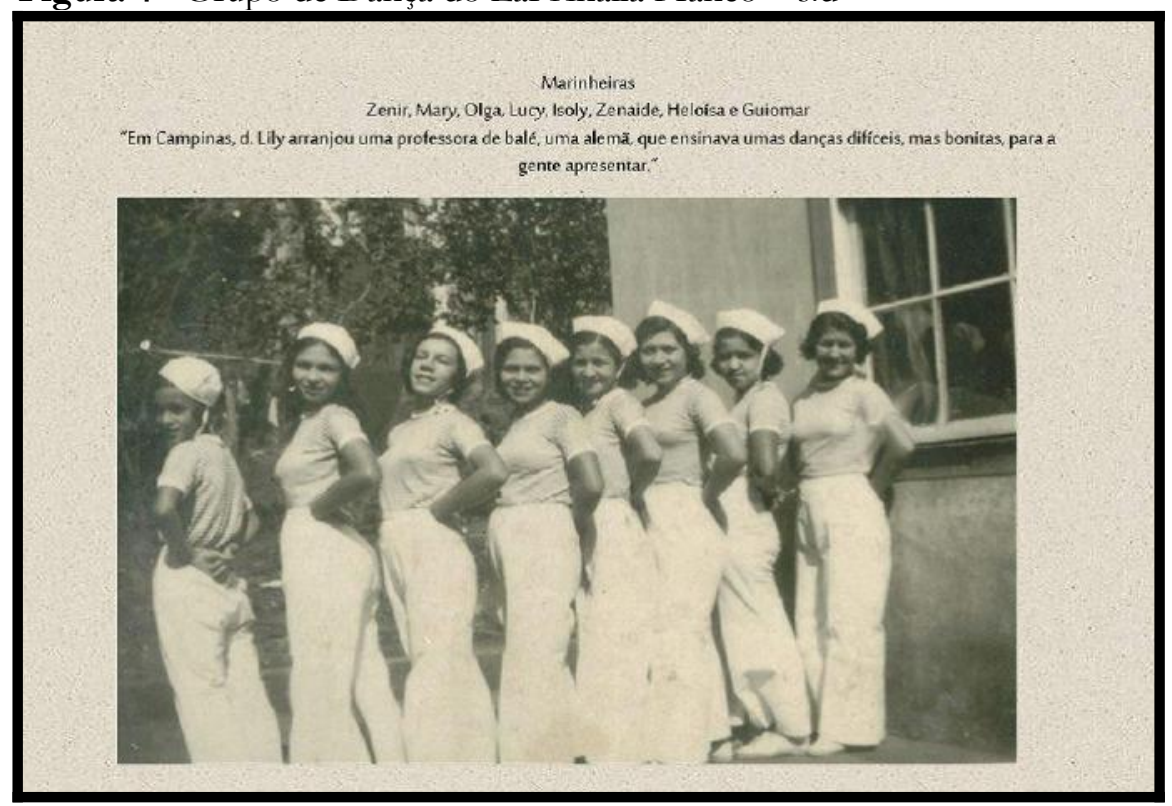

Fonte: Caselato (2003).

Chama a atenção, nas imagens apresentadas, a postura descontraída das garotas ao se posicionarem para o registro fotográfico. A espontaneidade e o sorriso estampado em seus rostos permitem supor que elas eram felizes na instituição, apesar de todas as adversidades que passaram enquanto sujeitos que desde pequenos estiveram longe de suas famílias.

\section{Considerações finais}

Embora tendo existência efêmera, o Asilo Anália Franco somou-se a outras instituições que no início do século XX prestaram assistência às crianças pobres que viviam em Uberaba, retirando-as das ruas e oferecendo-lhes diversas atividades educativas, inclusive o ensino primário.

Por meio das fontes encontradas também foi possível constatar que o dia a dia no Asilo era parecido com o de outras instituições que também atendiam ao público feminino: ensinava-se prendas domésticas e outras atividades consideradas apropriadas às mulheres. Contudo, de forma inusitada, as instituições idealizadas por Anália Franco diferenciaram-se das demais pela inclusão de atividades lúdicas e artísticas em suas práticas educativas.

Também chamou a atenção, ao longo da história do Asilo, as dificuldades encontradas devido ao fato de sua diretora manter vínculos com a 
doutrina espírita e a maçonaria. Supõe-se, assim, que não eram os sujeitos (no caso, as crianças) que estavam no centro das preocupações da sociedade e autoridades, mas a mensuração de forças que pudesse conferir maior ou menor legitimidade às religiões.

Nas primeiras décadas do século XX, conforme mencionado no início desse artigo, foram criadas em Uberaba sete instituições de assistência às crianças pobres. Destas, apenas três funcionam atualmente, ainda que em outros formatos.

Dentre as instituições extintas, o Asilo Anália Franco é a única que não permaneceu no imaginário coletivo da sociedade local, fato constatado pela raríssima menção à instituição em data posterior ao seu fechamento. Assim, enquanto as demais instituições foram diversas vezes rememoradas nos jornais locais e escritos memorialísticos, os dados sobre o Asilo ficaram restritos à literatura espírita, que geralmente é conhecida por um público específico.

Não se sabe se isso ocorreu devido à efemeridade da instituição em solo mineiro ou devido ao fato dela ter sido associada ao espiritismo, doutrina religiosa fortemente combatida naquela conjuntura. Faz-se necessário, portanto, a realização de novas pesquisas que possam somar-se a essa, possibilitando melhor compreensão da história do Asilo Anália Franco na cidade de Uberaba.

\section{Referências}

BRASIL. Decreto $\mathbf{n}^{\mathbf{0}}$ 17.943. Consolida as leis de assistência e proteção a menores. Rio de Janeiro, 12 de outubro de 1927, Vianna do Castello. [1927]. Disponível em:

http:/ /www2.camara.leg.br/legin/fed/decret/1920-1929/decreto-17943-a-12outubro-1927-501820-publicacaooriginal-1-pe.html. Acesso em: 6 set. 2020.

CAMURÇA, M. A. Fora da Caridade não há Religião: Breve História da Competição religiosa entre Catolicismo e Espiritismo Kardecista e de suas Obras Sociais na cidade de Juiz de Fora (1900-1960). Locus: Revista de História, [S. 1.], v. 7, n. 1, 2001. Disponível em:

https://periodicos.ufjf.br/index.php/locus/article/view/20538. Acesso em: 6 jul. 2021.

CARVAlHO, J. M. de. Cidadania no Brasil: o longo caminho. 21. ed. Rio de Janeiro: Civilização Brasileira, 2016.

CASELATO, E. S. O álbum de Olga. Carapicuiba, 2003. Disponível em: https://www.facebook.com/374417459400662/photos/a.374953772680364.1 $073741840.374417459400662 / 375137542661987 /$ ?type=3\&theater. Acesso em: 6 set. 2020 . 
ELOISA. Grandes pioneiros: Anália Franco. Revista Seareiro: órgão divulgador do Núcleo de Estudos Espíritas “Amor e Esperança”, ano 8, n. 66, p. 11, abr. 2007. Disponível em:

http://espiritismoeluz.org.br/seareiro/seareiro_04_2007.pdf. Acesso em: 6 set. 2020.

FERREIRA, I. Histórico da maçonaria em Uberaba. Uberaba: Vetha Editora e Gráfica, 1987.

GODOY, P. A. Grandes vultos do espiritismo. São Paulo: Edições FEESP, 1990.

GOFFMAM, E. Manicômios, prisões e conventos. Trad. Dante Moreira Leite. São Paulo: Editora Perspectiva S.A, 1974.

KISHIMOTO, T. M. A pré-escola em São Paulo: das origens a 1940. 1986. Tese (Doutorado em Educação) - Universidade de São Paulo, Faculdade de Educação, São Paulo, 1986.

KOSSOY, B. Realidade e ficções na trama fotográfica. 4. ed. São Paulo: Ateliê Editorial, 2009.

KOWARICK, L. Trabalho e vadiagem: a origem do trabalho livre no Brasil. 2. ed. Rio de Janeiro: Paz e Terra, 1994.

KUHLMANN JÚNIOR, M. A educação infantil no século XX. In: STEPHANOU, M.; BASTOS, M. H. C. (org.). Histórias e memórias da educação no Brasil. 3. ed. v III: Século XX. Petrópolis: Vozes, 2009.

KUHLMANN JÚNIOR, M. Infância e educação infantil: uma abordagem histórica. 7. ed. Porto Alegre: Editora Mediação, 2015.

LAVOURA E COMÉRCIO. Uberaba, 25/09/1919, edição nº 2.223, p. 6.

LAVOURA E COMÉRCIO. Uberaba, 23/10/1919, edição no 2.231, p. 3.

LAVOURA E COMÉRCIO. Uberaba, 09/11/1919, edição n 2.226, p. 2.

LAVOURA E COMÉRCIO. Uberaba, 11/12/1919, edição nº 2.245, p. 8.

LODI-CORRÊA, S. Anália Franco e sua ação sócio-educacional na transição do Império pra a República (1868-1919). 2009. Dissertação (Mestrado em Educação) - Universidade Estadual de Campinas, Faculdade de Educação, Campinas, 2009.

MONTEIRO, E. C. Anália Franco: a grande dama da educação brasileira. São Paulo: Madras, 2004. p. 265. 
OLIVEIRA, E. de C. Anália Franco e a Associação Feminina Beneficente e Instrutiva: ideias e práticas educativas para as crianças e para a mulher (18791920). Dissertação (Mestrado em educação) - Universidade São Francisco, Faculdade de Educação, Itatiba, 2007.

PATTO, M. H. S. Estado, ciência e política na Primeira República: a desqualificação dos pobres. Estud. av., São Paulo, v. 13, n. 35, p. 167-198, abr. 1999.

RIZZINI, I.; RIZZINI, I. A institucionalização de crianças no Brasil:

percurso histórico e desafios do presente. Rio de Janeiro: Ed. PUC-Rio, 2004.

SOUZA, M. A. A. A. O Orfanato Santo Eduardo e a assistência às crianças pobres em Uberaba - MG (1920 - 1964). 2018. Tese (Doutorado em Educação) - Universidade Federal de Uberlândia, Faculdade de Educação, Uberlândia, 2018. 